\title{
The Effects of a Shop's Functional Features on Children's Store Preferences
}

Jelena Filipović, Aleksandar Djordjevićc

Abstract:

The aim of this study is to examine how main store dimensions affect children's store preferences in Serbia. Four functional features of these marketplaces were investigated: price of merchandising in the store, the store's arrangement, the sales personnel's attitude towards children and the store's location. Findings suggest that different age cohorts of children react differently to each store's features. With only a few studies available that examine how the functional features of a store can affect children's store preferences in the most developed countries almost nothing is known about this topic in a country in transition such as Serbia. This paper should provide the basis for some future research in this field in the Serbian market and similar markets. Also, the managerial implications for retailers that are interested in the marketing positioning of their stores in the children's market are discussed.

Keywords: Serbian children market, store's features, store's preferences, favourite kids' shops

JEL: M19, M31

DOI: $10.2478 / v 10033-010-0020-5$

\section{Introduction}

The rising purchasing power of children throughout the last decades has brought to light yet another important segment of the consumer market. The importance of this market has been recognized both in marketing theory and practice. Research conducted by Sutherland and Thompson in 2001 revealed that children's consumption doubled in the 60 s, the 70 s and the $80 \mathrm{~s}$, while in the $90 \mathrm{~s}$ it tripled. Some authors estimate that the primary market in the USA accounted for $\$ 9$ billion in 1989 and for $\$ 20$ billion ten years later (McNeal 1992b, Davidson 1998).

According to McNeal (1992a) the children's market is usually divided into three broad groups: (1) the Primary market (2) the Market of influencers and (3) the Future market. While the above data mostly account for the children's primary market, it should be noted that the market of influencers it is even more significant. Namely, in 1992 this market was estimated at $\$ 132$ billion (Power et al. 1991, Step 1993) and at the beginning of the century accounted for $\$ 300$ billion (Rosenberg, 2000), affecting family purchases in 62 product categories (McNeal 1992b).

In addition to the indisputable growth in the economic power of children, it is important to understand that their role in consumption has also changed. According to McNeal (1999) and Siegel, Coffey and Livingston (2001), the main shifts in family structure and, therefore, in children's socialization are the following: (1) that families are becoming smaller; (2) the increasing number of single parents; (3) the rise in families' discretionary income; (4) that both parents work long office hours; (5) the greater number of children living in

\section{* Jelena Filipović}

Faculty of Economics in Belgrade, Serbia e-mail: jfilipovic@ekof.bg.ac.yu

\section{Aleksandar Djordjević}

Faculty of Economics in Belgrade, Serbia

e-mail: alexandar@ekof.bg.ac.yu 
stepfamilies; (6) giving children everything they want in an effort to make up for time not spent with them. Consequently, kids are becoming more independent and proactive in making purchasing decisions for a wide range of products.

As a result, children's responses to different instruments of integrated marketing communications (IMC) have also changed. However, while the marketing and marketing communications literature pays significant attention to the influence of advertising on children's shopping preferences and buying behaviour (McNeal 1999, Acuff and Reiher 1997), research on the effects of other IMC instruments is scarce. Some papers on this matter can be found in well established economies, such as the USA and European Union, yet transitional economies are completely understudied regarding this topic. This research found no previous study concerning this issue in Serbia or any other transitional country. However, we suppose that children in the Serbian market express purchasing behavior in a way similar to their counterparts in developed economies some time ago (when these economies were on a similar level of development regarding stores' formats and stores' atmosphere as Serbia is now).

On the other hand, the importance of store features as an IMC instrument in particular is highly relevant given that early children's consumer socialization starts in retail outlets where they learn their purchasing behaviour in the act of shopping (Moschias and Moore 1979, Ward 1974).

\section{Literature Review}

Despite relatively high research interest in the children's market, little is known about the factors influencing children's preferences of different stores. Yet we know that these preferences change according to the child's age (McNeal 1992b). For example, younger children (from the age of five through seven) prefer convenience stores and supermarkets for their ease of access and the product range they offer. In contrast, older children (ages 10-12) like the breadth of discount stores (mass merchandisers) and the depth of specialty stores (toy, sporting goods etc.)

In order to explore which store's qualities are crucial for creating a positive image in children's minds a number of authors focused on several important dimensions. Martineau (1958) defined four dimensions: symbols and colour, layout and architecture, advertising and sales personnel. The number of shop features became more numerous over time (Rachman 1975, De Pelsmacker, Geuens, and Bergh 2001) reaching 41 elements (Hansen and Deutscher 1977), including: product selection, sales personnel, location, interpersonal and impersonal communications.

While different authors focused on different store dimensions there were two store dimensions that were consistently found across all studies - affective (atmospheric) features and the functional characteristics of a store. Ghosh (1990) refers to affective features as "the psychological effect or feeling created by a store's design and its physical surroundings." One example of atmospheric dimensions would be the crowding and excitement at a retail store. Up to now there has been very little research on children's perceptions of affective qualities (Williams and Burns 2001). Nevertheless, affective qualities have impacts on consumers' perceptions of the functional attributes of a store (Sirgy and Samli 1985).

Functional aspects were examined much more thoroughly. They can be understood as the operational features of a marketplace, in fact the consumer's perception of the product, pricing and sales people (Weale 1961, Rachman 1975, Darden and Babin 1994). Williams and Burns (2001) argue that the "functional qualities of store image (i.e. merchandise selection, salesperson service, pricing) were strongly influenced by the child's global affective perception of the store's image". However, one very important functional element is usually disregarded, i.e. the location of a marketplace. Nevertheless, some findings show that children tend to like diversity and accessibility, as opposed to homogeneity and privacy (Talen and Coffindaffer 1999). McNeal (1999) identified the following main factors which make some stores preferred by children:

- Acceptable price ranges - older children are more sensitive to prices and respond more to sales

- Kid-friendly atmosphere - related to affective features of a store

- Kid's products - candies, toys, clothes, etc. Newly, some specialty retailers also entered the children market, including specialties as accessories, cosmetics, furniture, home furnishing, as well as catalog and online retailers (Siegel, Coffey and Livingston 2001)

- Eye-level accessible displays - they want products within their reach, they like to touch them, smell them and feel them in all possible ways 
- Kid-friendly store personnel who will try to help them and not treat them as an unwelcome customer

- Children favor stores favored by their parents and/or friends - children have a very intense urge to fit in their social environment

It should be noted that all previous studies highlighted three factors that determine children's attachment to a given shop: the prices of the goods that shop sells, the shop's arrangement/shop's atmosphere and the attitude of the shop's personnel, which is the reason why we focused on these elements in our own research. Some other factors could be considered relevant but are not consistently present in literature to the same extent as those just mentioned. However, we added also a fourth factor - the ease of access to the store, because we consider it to be a very important determinant of all children's everyday activities and something that cannot be omitted.

A review of the literature however reveals a strong gap in this particular field of study. With just a few studies examining how store functional features can affect children's store preferences in the most developed countries almost nothing is known about it in a country in transition such as Serbia. Therefore, this study aims to explore how the main functional store features affect children's store preferences in Serbia. Moreover, in our study we are particularly interested in finding out whether the influence of the main store features on children's store preferences differs according to the child's age.

\section{Research Hypotheses}

As explained above, our study focused on children's reactions to different functional features in stores. Among a number of factors examined by other authors, for the purposes of this research we focus on the following:

\section{1) Pricing as a functional feature}

By the time children are 8 or 9 years old, they understand the value of money, and they know that products have prices and know to look at price tags (McNeal and McDaniel 1981). A study conducted in 1995 showed that in a given sample almost three-quarters of children demonstrated price-consciousness. The same study revealed two important facts: a) kids care about price and this concern grows with development of their cognitive abilities (as they grow); b) children set upper limits on prices they will pay - mostly for moderately expensive products, such as toys and clothes (McNeal 1999).

In spite of this, children do not usually ask about price when seeking for product information before the purchase (Ward, Wackman, and Wartella 1977). Very few children know the prices for frequently purchased items (Stephens and Moore 1975).

Younger children tend to correlate prices and the physical features of a product. According to Fox and Kehret-Ward (1990), preschoolers usually determine prices based on the size of an item. Ten years old children know that price depends on the amount of production inputs required, while children at the age of 13 perceive price as the function of the quality of the product's inputs and the preferences of potential buyers (Turner and Brandt 1978). Thus, with an assumption that older children are more price sensitive, we hypothesized that:

H1: The importance of price as a criterion for a child's favorite store differs with her/his age

However, because our research concerned Serbia, a country in transition that faced a lack of goods, high inflation rate, high unemployment and low purchasing power throughout the last decade of the 20th century, high price sensitivity among all children market subgroups could be expected. Therefore, we assume that in general price has a high importance as a criterion for determining the favorite stores of children in Serbia, which is certainly greater than in other developed countries.

\section{2) Arrangement as a functional feature}

There are several aspects of a store that must be taken into consideration: merchandise selection, the color that prevails in its decoration, accessibility of shelves and general atmosphere. Williams and Burns (2001) argue that "the most important functional quality that influenced a child's loyalty for the discount store was the merchandise selection."

Another study (Clark 1997) points to the significance of colors. It states that children's favourite colours are purple, red, yellow, blue and green, whereas they dislike light, dark, smudgy or sophisticated colors. The same study advised against breaking standard flavor codes such as pink or red for strawberries, brown for chocolate, etc. 
Children feel comfortable in places associated with activity and social interaction (Talen and Coffindaffer 1999, Klepacki 1998) and retailers should provide them with those kinds of areas. Younger children like brightly coloured carpeting, low and rotating shelves, extra wide aisles, colourful displays, flexible fixtures and miniature shopping carts (Barr 1998, Sternman 1998).

Retailers have learned recently that shopping for kids is an environmental experience and thus the retail environment must meet this need. For example, the American retailer Limited Too, targeting primarily tween girls, offers girls in their stores sample nail polish and make-up, allows them to try on clothes, to try out furniture for their rooms, to look through popular magazines and finally, gives them candy (Siegel, Coffey and Livingston 2001). On the other hand, toy stores targeting preschoolers usually offer a different kind of ambience - for example, Turbo Limach, a regional toy retailer, provides children with the opportunity to create their own teddy bear, which employs a different store arrangement than the one previously mentioned (Limited Too).

Since this study has not found any previous research that addressed whether children of different ages react differently to the same store's arrangement, we based our second hypothesis on market observations:

H2: The significance of the store arrangement as a criterion for the child's favorite store differs according to the child's age

\section{3) Sales personnel as a functional feature}

A child's most distinct needs are to be loved and accepted by its peers and parents (Acuff and Reiher 1997). Therefore, they like spaces which are friendly, where they feel safe and protected. Despite the fact that some findings show that salespeople have almost no effect on children's store loyalty (Williams and Burns 2001) the significance of shop personnel should not be neglected.

Children prefer salespeople who are kid-focused, enthusiastic and who treat them with respect (Barr 1998). Hence, we hypothesized that the kindness of salespeople is important equally for both younger and older children.

H3: Salespeople's attitude towards children is important for children of all ages, in order to perceive a given store as their favourite.

"A store that greets children, provides gifts for children (cookies, balloons, e.g.) and has shopping facilitators for children (scaled-down shopping carts, eye- level displays, e.g.) will attract children and make a good impression on them - an impression, incidentally, that may last a lifetime." (McNeal 1992b).

\section{4) Ease of access as a functional feature}

Surprisingly, there have been almost no studies that address this aspect of a store, with regard to children's preferences in that marketplace. It could be concluded naturally that this is the crucial factor which determines whether a given shop is preferred more by children. However, McNeal (1992b) argues that due to the fact that children are limited by transportation and their parents' permission to visit stores they may spend money in stores that are convenient for them (on their way from home to school) even though the stores rate low on their preference scale. We hypothesized the following:

H4: The importance of accessibility as a criterion for a child's favorite store differs according to the child's age

\section{Research Design}

Studies conducted in this field can be grouped into two categories according to the methodology they have applied: i) those using experimental research and ii) those based on a survey of consumer attitudes. The second methodology is more common and our survey belongs to this category. In line with the fact that all previous studies conducted in this field (and with this type of respondents) have used the survey approach and that surveys are the most efficient method for broad samples, we opted for this method.

Our survey was organized as a self-administered survey with convenience sampling. The sample population consisted of children 7-8 and 12-13 years old who attended six schools in five cities (with two schools in the capital city) all over the territory of Serbia. These age cohorts were chosen based on psychological findings related to child development. It must be stated herein that the segmentation of children based on their age vastly differed from author to author. There is no universally accepted framework that reflects child development stages regarding the choice of stores. In marketing surveys concerning the children's market the most-commonly used is Piaget's theory, which proposes 4 main stages of cognitive development: birth to age 2, 27, 7-11 and 11 through adulthood (Roedder-John 1999). However, it is very difficult to find consistent opinion on the matter of drawing sub-segments within these quite 
broad segments. For example, Siegel, Coffey and Livingston (2001) consider children 8-12 years old a specific consumer group, Lindstrom and Seybold (2003) deem that children aged 8-14 have similar consumption patterns, while McNeal (1992a, 1999) does not distinguish between children's age groups at all. However, many authors (McNeal 1999, Maricic 2009, Roedder-John 1999) suggest that children from the age of 7 are sufficiently developed and can make independent decisions, selfevaluate and articulate perceptions

\begin{tabular}{|c|c|c|c|c|}
\hline City & Age & Boys & Girls & Total \\
\hline \multirow{5}{*}{ Belgrade } & 7 & 23 & 21 & 44 \\
\hline & 8 & 40 & 22 & 62 \\
\hline & 12 & 25 & 31 & 56 \\
\hline & 13 & 24 & 27 & 51 \\
\hline & & 112 & 101 & 213 \\
\hline \multirow{5}{*}{ Valjevo } & 7 & 12 & 10 & 22 \\
\hline & 8 & 9 & 8 & 17 \\
\hline & 12 & 9 & 11 & 20 \\
\hline & 13 & 8 & 7 & 15 \\
\hline & & 38 & 36 & 74 \\
\hline \multirow{5}{*}{ Nis } & 7 & 10 & 11 & 21 \\
\hline & 8 & 10 & 12 & 22 \\
\hline & 12 & 9 & 17 & 26 \\
\hline & 13 & 10 & 12 & 22 \\
\hline & & 39 & 52 & 91 \\
\hline \multirow{5}{*}{ Novi Sad } & 7 & 7 & 15 & 22 \\
\hline & 8 & 6 & 14 & 20 \\
\hline & 12 & 6 & 11 & 17 \\
\hline & 13 & 14 & 14 & 28 \\
\hline & & 33 & 54 & 87 \\
\hline \multirow{5}{*}{ Sabac } & 7 & 10 & 9 & 19 \\
\hline & 8 & 11 & 12 & 23 \\
\hline & 12 & 8 & 9 & 17 \\
\hline & 13 & 10 & 11 & 21 \\
\hline & & 39 & 41 & 80 \\
\hline Total & & 261 & 284 & 545 \\
\hline
\end{tabular}

Table 1: Survey plan

For the survey we developed two types of questionnaires - one for the age group 7-8 and the other for children between 12-13 years old. The questionnaire for the younger group was in color, containing drawings and pictures, while for the older group it was black and white and included less graphic objects. The total list of respondents broken down by city, age and gender is provided in Table no. 1. As can be seen in the previous table (no. 4.1.), the number of male and number of female respondents is almost equal ( $48 \%$ and $52 \%$, respectively). There were 500 usable questionnaires, while $9 \%$ had to be discarded. Even though the questionnaires were selfadministered, the authors were present for assistance. All children were asked to complete a questionnaire during a class.

\section{Findings and Discussion}

In order to test our hypotheses we transformed the questions into four variables. Since all the results are represented as proportions, we performed a chi-square test of independence. The aim of this test is to examine whether two variables are independent or not. The chisquare test is commonly used to compare observed data with data we would expect to obtain according to a specific hypothesis. This statistic always tests a null hypothesis which states that there is no significant difference between the expected and observed result. Given that the collected data was ordinal in format, a goodness-of-fit test could not have been performed. The significance level in all four cases was set up at $p \leq 0.05$.

It should be noted that in the second column of table 2, the possible answers to all questions in the questionnaire were "yes" or "no". Each respondent had to choose a maximum of three out of six store features that make that store her/his favorite. As can be observed in the following table, the number of degrees of freedom is one in all cases. The standard level of chi-square statistics, at the significance level of $p \leq 0.05$ and $d f=1$ is 3.841 .

First, it has been proved in previous studies (listed in the second part of this paper), that children's sensitiveness to prices differs by their age. This statement was proven for Serbia as well $(p=0.000)$. Actually, the value of the chi-square test is 14.671 , which is more than 3.841 , so we cannot accept research hypothesis $\mathrm{H} 1$. It has already been stated that children in Serbia experienced a severe lack of pocket-money and goods during the 90s; therefore, it is not surprising that $34 \%$ of children between the ages of 7 and 8 prefer stores that sell cheap products. However, it is surprising that only $19 \%$ of children in the older cohort share the same point of view. This could be explained by the fact that 12 and 13-yearolds care more about peers' opinions (Siegel, Coffey, and Livingston 2001) and consequently, favor stores that most of their friends prefer, not taking into account the prices of the merchandise. 


\begin{tabular}{|c|c|c|c|c|c|c|}
\hline \multirow{2}{*}{$\begin{array}{c}\text { Examined store's } \\
\text { feature }\end{array}$} & & \multicolumn{2}{|c|}{ Child's age } & \multirow[b]{2}{*}{ Total } & \multirow{2}{*}{$\begin{array}{c}\text { Pearson } \\
\text { Chi-Square } \\
\text { Value } \\
\end{array}$} & \multirow[b]{2}{*}{ p-value } \\
\hline & & $7-8$ & $12-13$ & & & \\
\hline \multirow{2}{*}{ Cheap prices } & yes & 83 & 49 & 132 & \multirow{3}{*}{14,671} & \multirow{3}{*}{0,000} \\
\hline & no & 159 & 207 & 366 & & \\
\hline Total & & 242 & 256 & 498 & & \\
\hline \multirow{2}{*}{ Arrangement } & yes & 84 & 104 & 188 & \multirow{3}{*}{1,757} & \multirow{3}{*}{0,196} \\
\hline & no & 157 & 152 & 309 & & \\
\hline Total & & 241 & 256 & 497 & & \\
\hline \multirow{2}{*}{$\begin{array}{l}\text { Kind } \\
\text { sales personnel }\end{array}$} & yes & 122 & 86 & 208 & \multirow{3}{*}{13,841} & \multirow{3}{*}{0,000} \\
\hline & no & 122 & 170 & 292 & & \\
\hline Total & & 244 & 256 & 500 & & \\
\hline \multirow{2}{*}{$\begin{array}{l}\text { Vicinity of store to child's } \\
\text { school } \\
\text { or home }\end{array}$} & yes & 131 & 55 & 186 & \multirow{3}{*}{55,460} & \multirow{3}{*}{0,000} \\
\hline & no & 113 & 201 & 314 & & \\
\hline Total & & 244 & 256 & 500 & & \\
\hline
\end{tabular}

Table 2: Results of chi-square test

In contrast to our expectations, there is no statistically significant difference in store decoration appreciation between the two groups of children $(p=0.196$, chisquare $=1.757<3.841$ ). Namely, $40.6 \%$ of the older group and $34.8 \%$ of the younger group evaluates a shop by this feature. This finding can be very beneficial for managers in creating a distinct advantage for their business in the children's market in Serbia. It should be noted that the results show that younger children have equal concerns about prices and the store's arrangement, whereas older children care more about the shop's decoration than the prices of its merchandise.

At this point, in order to have a better understanding of the chi-square value in the table (13.841), it would be useful to remind that $\mathrm{H} 3$ stated that the kindness of salespeople is equally important for both younger and older children. With regard to the fact that there is no evidence that there is a relation between children's age and their store's preferences based on sales personnel attitude, we can conclude that all children equally care how they are treated by marketplace staff.

The final hypothesis was used to examine the importance of the store's location as a functional feature. It is clear from table 2 that the significance of this shop's aspect varies with the child's age $(p=0.000$, chisquare $=55.460>3.841)$. More than half $(53.7 \%)$ of children aged 7-8 stated that their favorite marketplace is near their school or home. This finding is in accordance with McNeal's study (1992b), which discovered that young children prefer convenience stores. Most probably they are not allowed by their parents to go to distant parts of town, so they have to shop in their neighborhoods. In contrast, $21.5 \%$ (which is less than half of the number of younger respondents that chose this answer for the same question) of older kids stressed this feature as important for their favorite store.

\section{Conclusions, Limitations and Further Research}

\section{Directions}

To sum up, there are several conclusions that could be drawn from this research: a) younger cohorts (7-8 years old) are very concerned with prices, while older cohorts primarily care about the image of the store and how it reflects on their personal image; b) all children equally care about the shop's arrangement and therefore this is one of the most prominent aspects that could be changed in order to help sales; c) not surprisingly, for children it is very important how they are treated by marketplace staff; this is a crucial store feature to have loyal young customers; d) one of the least investigated among store aspects - vicinity to children's homes or schools, was proven to be very important for younger children, while far less so for older ones.

Several limitations to this study can be listed here. One of the most common is that the sample used in this survey was a convenience sample. As such, the representativeness of the sample cannot be determined. Secondly, all collected data was given as proportions, so the only suitable statistic was the chi-square test, which provides us with fewer results and is less accurate than other statistics. The answers format can be justified by the inability of children to evaluate the degree of their emotions on appropriate scales. 
Furthermore, the survey was conducted only in cities, and consequently we cannot draw conclusions about the attitudes of rural children towards store features. We can also only assume that there would be statistically significant differences with regard to favorite stores according to the children's towns of residence, because some sales places (e.g. shopping malls) are not equally present in Serbian territory, but our research cannot examine this fact due to low numbers. Finally, this is the first study in this field in Serbia, so it was not possible to examine the shift in children's preferences over time. Moreover, there is a lack of studies regarding this topic in other transitional countries, so such a comparison was not possible.

Future research directions should include extending this research to investigating and understanding child preferences regarding shops' features in other countries above all, in other Eastern European countries in transition. In addition, research could be extended to understanding other important aspects of children's favorite marketplaces in addition to the aspects addressed in this study. A detailed and thorough survey should also examine children's preferences with regard to the type of store (supermarkets, toy stores, book stores, etc.). ㄷ.

\section{References}

Acuff, D. S. and Reiher, R. H. 1997. What Kids Buy and Why. New York: The Free Press

Baar, A. 1998. New CME Unit Takes Child's Play Seriously. Adweek 39(14), 7

Clark, S.H.L. 1997. How Packaging Works with Children. In: Smith, G. (eds.), Children's Food Marketing and Innovation. London: Chapman \&Hall, 119-125

Darden, W. R. and Babin, B. J. 1994. Exploring the Concept of Affective Quality: Expanding the Concept of Retail Personality. Journal of Business Research 29, 101-109

Davidson, K. 1998. Opportunities, threats when marketing to kids. Marketing News. August 17, 10

DePelsmacker, P., M. Geuens and Van den Bergh, J. 2001. Marketing Communications, Harlow: Pearson Education

Fox, K. and Kehret-Ward, T. 1990. Naïve Theories of Price: A Developmental Model. Psychology and Marketing 7, 311-329

Ghosh, A. 1990. Retail Management. Orlando: Dryden Press

Hansen, R. and Deutscher, T. 1977. An Empirical Investigation of Attribute Importance in Retail Store Selection. Journal of Retailing 53, 58-72

Klepacki, L. 1998. Courting the 'Tweenie' Boppers. WWD 38 (175), 10

Lindstrom, M. and Seybold, P.B. 2003. Brandchild: insights into the minds of today's global kids, Martin Lindstrom and Individual Contibutors, London, 2003

Maricic, B. 2009. Consumer Behaviour (edition in Serbian). $8^{\text {th }}$ edition. Belgrade: CID of Faculty of Economics
Martineau, P. 1958. The Personality of the Retail Store. Harvard Business Review 36, 47-55

McNeal, J. U. 1992a. Kids as Customers - A Handbook of Marketing to Children. New York: Lexington Books

McNeal, J. U. 1992b. The Littlest Shoppers. American Demographics. February, 48-53

McNeal, J. U. 1999. The Kids Market - Myths and Realities. New York: Paramount Market Publishing Inc.

McNeal, J. U. and McDanie, S. W. 1981. Children's Perceptions of Retail Stores: An Exploratory Study. Akron Business and Economic Review 12 (3). 39-42

Moschis, G. and Moore, R. L. 1979. Mass Media and Personal Influences on Adolescent Consumer Learning. In: Developments in Marketing Science 2. Gitlow and Wheatley (eds.) Greenvale, NY: Academy of Marketing Science, 126-130

Power, C., S. Atchison, G. De-George and Foust, D. 1991. Getting 'Em While They're Young. Business Week. September 9, 94-95

Rachman, D. J. 1975. Retail Strategy and Structure. Englewood Cliffs (N. J.): Prentice Hall

Roedder-John, D. 1999. Consumer Socialization of Children: A Retrospective Look at Twenty-Five Years of Research. Journal of Consumer Research 26. December, 183-213

Rosenberg, J. 2000. Agencies pile on the resources. Advertising Age 71 (7), 45

Siegel, D. L., T. J. Coffey and Livingston, G. 2001. The Great Tween Buying Machine. New York: Paramount Market Publishing, Inc.

Sirgy, M. J. and Samli, A. C. 1985. A Path Analytic Model of Store Loyalty Involving Self-Concept, Store Image, Geographic Loyalty, and Socioeconomic Status. Journal of the Academy of Marketing Science 13, 265-291

Stephens, L. and Moore, R. L. 1975. Price Accuracy as a Consumer Skill. Journal of Advertising Research. August 15, 27-34

Sternman, M. 1998. Child's Play. Supermarket News 48 (4), 22-23

Stipp, H. 1993. New Ways to Reach Children. American Demographics. August. 50-56

Sutherland, A. and Thompson, B. 2001. Kidfluence: Why Kids Today Mean Business. 1st edition. New York: Paramount Market Publishing

Talen, E. and Coffindaffer, M. 1999. The Utopianism of Children: An Empirical Study of Children's Neighborhood Design Preferences. Journal of Planning Education and Research 18 (4), 321-331

Turner, J. and Brandt, J. 1978. Development and Validation of a Simulated Market to Test Children for Selected Consumer Skills. Journal of Consumer Affaires 12, 266-276

Ward, S., Wackman, D. B. and Wartella, E. 1977. How Children Learn to Buy. Beverly Hills: Sage Publications

Weale, B. W. 1961. Measuring the Customer's Image of the Department Store. Journal of Retailing. Summer, 40-48

Williams, L. A. and Burns, A. C. 2001. Factors Affecting Children's Store Loyalty: An Empirical Examination of Two Store Types. Journal of Applied Business Research 17 (1), 61-82 